
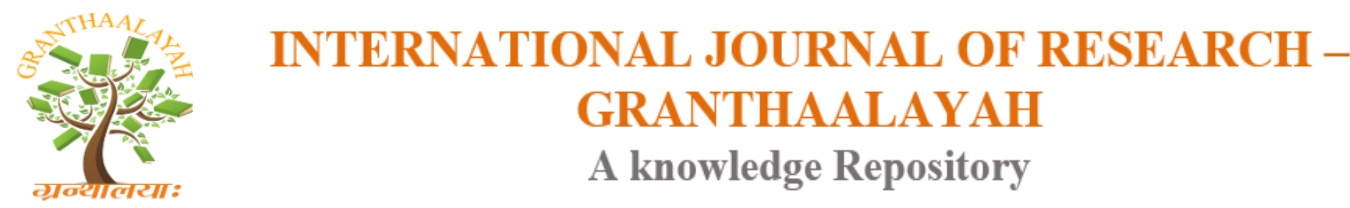

Science

\title{
MUTRASHMARI: REVIEW OF LITERATURE
}

\author{
Dr. Sachin Waghmode ${ }^{1}$, Dr. Sachin Waghmare ${ }^{2}$ \\ ${ }^{1}$ P.G.Scholar, Department of Ayurved Samhita and Siddhant, Y.A.C.P.G.T \& R.C, Kodoli, \\ Kolhapur, India \\ ${ }^{2}$ Guide, Department of Samhita, Y.A.C.P.G.T \& R.C, Kodoli, Kolhapur, India
}

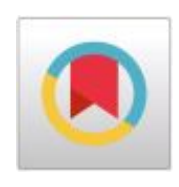

\begin{abstract}
Mutrashmari is a very common disease which includes a complex physiochemical process that involves a series of events in formation of ashmari i.e. stone. Incidence of mutrashmari has raised due to changed standard of living and is strongly associated with race, ethnicity and region of residence. Pathya-apathya is an important factor in mutrashmari. Description of mutrashmari is available in almost all samhita. In Ayurveda, both shaman and shodhan chikitsa is described for the treatment of mutrashmari. Acharya sushrut has mentioned shaman chikitsa like use of ghrita (medicated ghee), taila (medicated oil), paneeya kshara etc. which possess properties like chedana, bhedana, lekhana and mutala before opting for surgical intervention.
\end{abstract}

Keywords: Mutrashmari; Literature; Ashmari.

Cite This Article: Dr Sachin Waghmode, and Dr. Sachin Waghmare. (2017). "MUTRASHMARI: REVIEW OF LITERATURE." International Journal of Research - Granthaalayah, 5(10), 209-213. https://doi.org/10.29121/granthaalayah.v5.110.2017.2297.

\section{Introduction}

Ashmari is a disease related to mutravaha strotas in which an 'ashma' meaning stone is formed in urinary system. It is a tridoshaj vyadhi with predominant kapha dosha. This disease is classified on the basis of signs and symptoms as well as morphology of stone that are formed in different part of mutravaha strotas.

Though ashmari comes under 'ashta mahagada' number of drugs, kshara and ghrita are proved to be useful in ashmari. These drugs act as bhedana and patana, vedanashamak, bastishodhak. If ashmari are developed bigger in size, it is not possible to treat them medically and in this case surgical intervention is necessary. There are possibilities of recurrence of ashmari and therefore care should be taken for prevention.

\section{Definition}

Ashmaris are structures like hard stone. 


\section{Classification}

1) Vataja

2) Pittaja

3) Kaphaja

4) Shukrashmari

\section{Nidan}

- Ushna gaman/gharma gaman - walking / working in sun for a long time.

- an individual working in direct sun for a longtime, who perspires alot may generally cause concentrated urine and reduction in urine volume, leading to formation of ashmari.

- Adhwagaman / deerghamarga gaman - regular habit of walking longer distance causes ashmari due to excess perspiration.

- Asamshodhan sheelasya - individual who needs samshodhana but has not undergone samshodhana karma time to time and indulges in kapha dosha aggravating aahar vihar leading to development of ashmari.

- Prayena sheeta snigdha guru madhura aahar - excessive intake of madhura, snigdha, guru aahar such as dugdha, mansa etc. causes ashmari as such aahar aggravate kapha dosha and also are rich in calcium, purine, phosphate etc. hence they lead to formation of ashmari. The word prayena in this context refers to that kapha dosha provoking factors cause ashmari only in those individuals who are susceptible to it.

- Apathya kaarinaha - not following the diet and regimen recommended in ashmari.

- Adhyashana / samashana - consuming the food before digestion of previously ingested food / over eating. Causes increase in kapha dosha in body.

- Divaswaap

- Mutravegavrodha - suppression of micturition or infrequent urinary drainage may lead to stone formation.

\section{Samprapti}

- Mutrashmari is a kapha dominant tridoshaja vyadhi occurring in any part of urinary tract.

- The vitiated vata dosha alongwith kapha dosha in mutravaha strotas leads to ashmari formation. There is reduction in volume of urine due to saturation of kapha dosha in urine thus causing formation of ashmari.

- Kapha dosha is samavayi karana of ashmari. The predominant kapha dosha gets hard and develops in the form of ashmari.

- As the vitiated shleshma enters mutravaha strotas alongwith urine, ashmari is formed. The process of formation of ashmari is very gradual.

- While explaining the formation of ashmari acharya sushruta narrates that, the manner in which even clean water collected in pot precipitates in the bottom after sometime; similarly the process of hardening of ashmari occurs with the kshara of kapha dosha present in mutravaha strotas 


\section{According to yogaratnakara}

When aggravated vata dosha settles down in basti pradesha, by virtue of its ruksha guna it dries up the locally available mutra, shukra and pitta to convert them to 'sharkara' i.e.granules.Kapha dosha by its guru, sandra, snigdha, pichila guna and alepana karma i.e.binding mechanism, binds those granules together to make a soft stone like structure. Pitta by its paka karma completes the stone formation process.

\section{Purvarupa}

Purvarupa mentioned in samhitas are also observed in rupavastha of ashmari.

- Basti adhamanam - distension of bladder due to retention of urine

- Aasannadeshe ruja - severe pain at the site of ashmari

- Bastishirovedana - pain in suprapubic region

- Bastipeeda - pain in hypogastric region

- Mutrakrichra - difficulty in micturition due to irritation of bladder by calculus and also infection caused due to it

- Dushtasandramutrata - sedimentation of urine

- Aavilamutrata - turbidity of urine

- Bastagandhatwam - concentrated urine smells like goat's urine

- Aruchi-anorexia

- Jwara - fever (indication of urinary tract infection due to renal stone)

\section{Samanya lakshana}

- Nabhi-sevani-basti-mehan-sira ruk - intense pain at umbilical region, perineal region, suprapubic region, genitalia

- Visheernadhara mutram - obstructed flow of urine

- Aayasaat atirukbhavet - pain aggravates on unusual positions like riding bike,horse, jumping, travelling etc.

- During migration of stone from urinary tract injury occurs, due to injury haematuria occurs.

\section{Vishesh lakshana}

Vataja mutrashmari - it occurs due to predominant vata dosha. There is severe pain, dysuria (mutrakrichrata); difficulty in movement/ expulsion of mutra, purisha. Pain in vataja ashmari is described as -

Morphological structure of vataja ashmari - kantakachitam (spiky), parusham (rough), visham (irregular), khara/kathina (hard); shape of ashmari is like that of 'kadamba pushpa' (irregular surface-appears like flower of kadamba).

Resembles - uric acid stone

Pittaja mutrashmari - when pitta is associated with kapha dosha pittaja ashmari is formed. There is burning sensation (daha), pain (peeda); blood strained urine. 
Morphological structure of pittaja ashmari - sarakta, krushna, peeta, madhuvarna, bhallataka asthipratima i.e. shape resembles 'bhallatakasthi'.

Resembles - calcium oxalate, uric acid and cystine stone

Shleshmaja mutrashmari - due to over indulgence of kapha aggravating factors ashmari is formed. Kaphaja ashmari is bigger in size therefore there is pain in bladder like 'suchibhairava' i.e. needle pricks; knaving, pulling type of dull ache is experienced by patient.

Morphological structure of kaphaja ashmari - shweta, madhuvarna, sitavarna, madhukapushpavarna, pingal shuklavarna; ashmari shape resembles 'egg' shape (kukkutanda pratikasha).

Resembles - calcium phosphate stone

Shukraja ashmari - uppression of shukra vega is main cause of formation of shukrashmari. There is pain at basti region; difficulty in micturition; swelling in scrotum.

Yogaratnakara described the onset of mutrashmari in below three stages -

1) severe pain in kukshi, kati region

2) burning micturition

3) Urinary flow obstruction.

\subsection{Upadrava}

Panduta - as diseased kidney cannot secrete erythropoietin, anemia occurs Karshya - longstanding dormant renal calculi may give rise to wasting of muscle Ushnavata, kukshishoola, trushna, hrutpeeda, aruchi, vami

\subsection{Asadhya lakshana}

Prashuna nabhi vrushan, baddhamutra, ruja, ashmari sikata sharkaranvita.

\subsection{Chikitsa}

Medical management consists of diet and drugs designed to reduce the risk factors of ashmari formation. The most vital modification in diet is adequate fluid intake throughout the day to produce a minimum of 2 litres of urine. Reduction of salt intake to less than $4 \mathrm{~g} /$ day is recommended.

\subsection{Samshodhana Therapy}

Snehana, swedana, virechana, basti and uttarbasti are recommended measures with use of suitable drugs. 
Ashmari chikitsa can be divided into

1) purva rupavastha

2) rupavastha

3) prevention of relapse/ recurrence

\subsection{During purvarupa}

In ashtang hridaya chikitsasthan and yogaratnakara, following measures are recommended during prodromal state of ashmari.

Snehana, swedana, vamana, adhika ambupana, avagaha sweda

\subsection{Rupavastha}

virechana, uttara basti with ashmari bhedana. By these measures mutramarga shodhana takes place and apana vayu movements are stimulated.

\section{Aushadhi yojana}

Drugs acting with following properties should be used.

- Ashmari bhedana - promotes crushing of ashmari

- Ashmari paatana - helps in flushing out of ashmari of small size

- Mutrala /bastishodhak - promotes diuretic action

- Mutra shulaghna/ basti shulaghna - relieves pain (spasmolytic action)

- Mutrakrichrahara - soothing and antimicrobial action against urinary pathogens

- Mutranulomak/ mutravibandhaghna - helps in relieving the barrier caused by ashmari

- Pittashamak - soothing action

- Kshiprameva bhinnati - promotes crushing of stone quickly

- Chirakari ashmaril praghadha ashmarihara - helps in flushing chronic and dormant stones located in kidney.

\section{Important drugs used in ashmari}

Pashanabheda, Gokshura, Shilajit, Varuna, Usheera, Karkatika, Trapusa.

\section{References}

[1] Charak samhita Vol 1, Vd Brahmanand Tripathi, Chaukhamba prakashan, Reprint 2014.

[2] Sushrut samhita Vol 2, Vd Ambikadatta Shastri, Chaukhamba prakashan, Reprint 2013.

[3] Ashtang Hridayam, Vd. Brahmanand Tripathi, Chaukhamba prakashan, Reprint 2009.

[4] Madhav Nidan Vol 1, Vd. Yadunandopadhya, Chaukhamba prakashan, Reprint 2008.

[5] Yogratnakar, Vd. Lakshmipati Shastri, Chaukhamba prakashan, Reprint 2009.

[6] Bhavaprakash, Vd. Bhavashankar Mishra, Chaukhamba prakashan, Reprint 2010.

*Corresponding author.

E-mail address: gauravkumar.shaha@ gmail.com 